\title{
Nitric Oxide Scavenging by Red Cell Microparticles and Cell Free Hemoglobin as a Mechanism for the Red Cell Storage Lesion
}

\author{
Chenell Donadee, MD ${ }^{1,2}$, Nicolaas J.H. Raat, $\mathrm{PhD}^{1,2,3}$, Tamir Kanias, $\mathrm{PhD}^{1}$, Jesús Tejero, \\ $\mathrm{PhD}^{1}$, Janet S. Lee, MD ${ }^{1,2}$, Eric E. Kelley, $\mathbf{P h D}^{1,4}$, Xuejun Zhao, $\mathrm{PhD}^{1,2}$, Chen Liu, BS ${ }^{5}$,

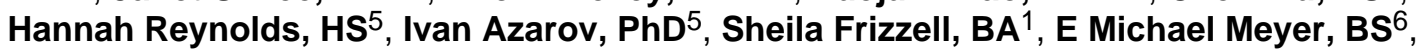 \\ Albert D. Donnenberg, PhD $^{6,7}$, Lirong Qu, MD, PhD ${ }^{8,9}$, Darrel Triulzi, MD ${ }^{8,9}$, Daniel B. Kim- \\ Shapiro, $\mathrm{PhD}^{5,{ }^{*}}$, and Mark T. Gladwin, MD ${ }^{1,2,{ }^{*}}$
}

${ }^{1}$ Vascular Medicine Institute, University of Pittsburgh, Pittsburgh, PA, $15213{ }^{2}$ Department of Medicine, Division of Pulmonary, Allergy and Critical Care Medicine, University of Pittsburgh School of Medicine, Pittsburgh, PA, $15213^{3}$ Department of Experimental Anesthesiology, Erasmus Medical Center, Rotterdam, The Netherlands ${ }^{4}$ Department of Anesthesiology, University of Pittsburgh School of Medicine, Pittsburgh, PA $15213^{5}$ Department of Physics, Wake Forest University, Winston-Salem, NC $27109^{6}$ University of Pittsburgh Cancer Institute, Pittsburgh, PA $15203^{7}$ Department of Medicine, Division of Hematology/Oncology, University of Pittsburgh School of Medicine, Pittsburgh, PA $15213^{8}$ Department of Pathology, University of Pittsburgh School of Medicine, Pittsburgh PA $15213^{9}$ Institute for Transfusion Medicine, Pittsburgh PA

\section{Abstract}

Background-Intravascular red cell hemolysis impairs NO-redox homeostasis, producing endothelial dysfunction, platelet activation and vasculopathy. Red blood cell storage under standard conditions results in reduced integrity of the erythrocyte membrane, with formation of exocytic microvesicles or "microparticles" and hemolysis, which we hypothesized could impair vascular function and contribute to the putative "storage lesion" of banked blood.

Methods and Results-We now find that storage of human red blood cells under standard blood banking conditions results in the accumulation of cell free and microparticle-encapsulated hemoglobin which, despite 39 days of storage, remains in the reduced ferrous oxyhemoglobin redox state and stoichiometrically reacts with and scavenges the vasodilator nitric oxide (NO). Using stopped-flow spectroscopy and laser triggered NO release from a caged NO compound we found that both free hemoglobin and microparticles react with NO about 1000 times faster than with intact erythrocytes. In complementary in vivo studies we show that hemoglobin, even at concentrations below $10 \mu \mathrm{M}$ (in heme), produces potent vasoconstriction when infused into the rat circulation, while controlled infusions of methemoglobin and cyanomethemoglobin, which do not consume NO, have substantially reduced vasoconstrictor effects. Infusion of the plasma from stored human red cell units into the rat circulation produces significant vasoconstriction related to the magnitude of storage related hemolysis.

Address correspondence to: Dr. Mark T. Gladwin, Pulmonary, Allergy and Critical Care Medicine, University of Pittsburgh, Phone: 412-692-2210; Fax: 412-692-2260; gladwinmt@ upmc.edu ; or Dr. Daniel B. Kim-Shapiro, Department of Physics, Wake Forest University, Phone:.336-758-4993; Fax: 336-758-6142; shapiro@wfu.edu..

*Shared senior authors.

Disclosures Drs. Gladwin and Kim-Shapiro are coauthors on patent applications related to treating hemolysis.

This is a PDF file of an unedited manuscript that has been accepted for publication. As a service to our customers we are providing this early version of the manuscript. The manuscript will undergo copyediting, typesetting, and review of the resulting proof before it is published in its final citable form. Please note that during the production process errors may be discovered which could affect the content, and all legal disclaimers that apply to the journal pertain. 
Conclusions-The results of these studies suggest new mechanisms for endothelial injury and impaired vascular function associated with the most fundamental of storage lesions, hemolysis.

\section{Keywords}

Hemoglobin; microparticles; nitric oxide; blood transfusion; storage lesion; reactive oxygen species

\section{Background}

Transfusion of blood represents one of the most common medical therapies with over 14.5 million packed red blood cell units, or 48.9 units per thousand persons, administered in the United States per year. ${ }^{1}$ It is remarkable that approximately $40 \%$ of all critically ill adult patients receive at least one unit of packed red blood cells in the intensive care unit, with a mean of 5 units per patient. ${ }^{2-4}$ The five-unit mark is notable when one considers that this represents 50\% of the human blood volume. Since the 1960's multiple red cell transfusion, or "hypertransfusion", has been recognized as a risk factor for acute lung injury. It was first noted during the Vietnam War that "the lungs are a vulnerable target organ to a variety of pathogenetic stimuli," including blood. ${ }^{5-7}$ In recent years a growing body of literature has demonstrated an increased incidence of adverse clinical outcomes associated with the transfusion of a large number of units or, potentially, with increased storage time of the units. These events include increased risk of infection, renal failure, respiratory failure, multiple organ failure and death, particularly in physiologically compromised patient populations. ${ }^{8-13}$ This is an active area of investigation with competing studies suggesting a risk and others suggesting that storage duration risk is confounded by the number of units transfused and associated severity of illness. ${ }^{14,15}$

The Food and Drug Administration and American Association of Blood Banks currently permit blood preserved in ADSOL solution to be stored for 42 days. Stored red blood cells undergo a number of morphologic and biochemical changes with increased storage time. ${ }^{16,17}$ Morphologic changes include reduced deformability, increased osmotic fragility, and spheroechinocyte formation, associated with progressive reduction in the intracellular levels of ATP and DPG and dropping pH values. In addition, prolonged red cell storage favors oxidant stress conditions leading to lipid peroxidation, oxidation of membrane and cytoskeletal proteins and reduced integrity of the erythrocyte membrane. ${ }^{16-19}$ These and other changes in red blood cell functionality and integrity during storage are commonly referred to as the "storage lesion."

There is increasing hemolysis during packed red blood cell storage which increases cell free plasma hemoglobin over time. ${ }^{20-22}$ Fragmentation and formation of $50-100 \mathrm{~nm}$ microparticles, which contain a substantial amount of hemoglobin, also occurs as red blood cells age. ${ }^{21,23,24}$ According to current FDA guidelines, at the end of the storage period, only $75 \%$ of erythrocytes are required to be recoverable 24 hours after transfusion, suggesting that further hemolysis and microparticle formation occurs in vivo after transfusion, although much of this is likely extravascular red cell clearance. These findings are concerning as it is known that free hemoglobin reacts with the vasodilator nitric oxide (NO) in a 1:1 stoichiometric reaction that occurs at high rate of $6-8 \times 10^{7} \mathrm{~mol} / \mathrm{L} / \mathrm{s} .{ }^{25}$ This consumption of NO by cell free plasma hemoglobin has been shown to cause changes in vascular function in subjects with sickle cell anemia who had plasma heme concentrations as low as $6 \mu \mathrm{M}^{26}$ Approximately half of the observed "hemolysis" in stored blood is also encapsulated in microparticles, and, in theory, based on their small molecular size, microparticles may also exhibit accelerated NO scavenging rates compared with intact erythrocytes. ${ }^{27}$ The effect of microparticles on NO scavenging could be especially important, particularly in the 
microvasculature where their clearance may not be reflected by systemic clearance rates. Indeed, in a rat model, approximately $90 \%$ of red cell microparticles are cleared systemically by 30 minutes of injection and distribute predominantly into the liver but also throughout multiple organs such as the bone, kidneys, skin, and lungs. ${ }^{28}$ Hemolysis also decreases NO bioavailability by releasing red cell arginase-1, an enzyme that converts arginine to ornithine, thereby reducing arginine, a substrate for nitric oxide synthase. ${ }^{29,30}$

We therefore initiated in vitro chemistry and biophysical studies of stored blood cell free hemoglobin and microparticles and in vivo physiological studies with infusions of the plasma collected from fresh and aged stored human red cell units, to explore whether the formation of microparticles and accumulation of cell free hemoglobin during in-storage red blood cell hemolysis will increase the rate of NO catabolism and impair endothelial function. The results of these studies suggest new mechanisms for endothelial injury and impaired vascular function associated with the most fundamental of storage lesions, hemolysis.

\section{Methods}

\section{Packed red blood cells}

Nine randomly selected packed red blood cell units were obtained from the Central Blood Bank, Pittsburgh, PA. These units were non-leukoreduced and preserved in ADSOL solution, which is standard at the University of Pittsburgh Medical Center. Additional units that were leukoreduced were also studied for comparison. The units were stored in a temperature controlled refrigerator at $1-6^{\circ} \mathrm{C}$ and sampled weekly over 6 weeks starting at an age of 4 days old. At the end of storage samples were cultured to exclude bacterial contamination. Samples collected at weekly intervals were centrifuged at room temperature at $2700 \times \mathrm{g}$ for $20 \mathrm{~min}$. The supernatant was stored at $-80^{\circ} \mathrm{C}$ and later thawed for analysis of the free hemoglobin, NO consumption, electron paramagnetic resonance (EPR), hemoglobin spectral deconvolution, and arginase-1 assays as well as for in vivo infusion studies in a rat model as described below.

\section{Cell-free plasma hemoglobin levels and spectral deconvolution of species}

Cell free plasma hemoglobin was measured by conversion to cyanomethemoglobin using Drabkin's reagent and then measuring absorbance spectrophotometrically at 540nm. (Beckman Coulter DU 800 UV/Visible Spectrophotometer, Brea, CA). ${ }^{31,32}$ Hemoglobin concentration and spectra were also measured on an Agilent $8453 \mathrm{UV}$-Visible Spectrophotometer (Agilent Technologies, Santa Clara, CA) using $1 \mathrm{~cm}$ path length cuvettes. The concentrations of oxyhemoglobin and methemoglobin in the plasma samples were analyzed by deconvoluting the spectrum into components from standard UV-visible spectra of human hemoglobin composed of oxyhemoglobin, methemoglobin and deoxyhemoglobin in PBS buffer using a least-square method as previously described with some adjustments to correct for the background signal from plasma. ${ }^{33}$ Additional experimental detail are summarized in the on-line supplement.

\section{NO consumption}

The ability of the cell free hemoglobin in the supernatant to scavenge NO was measured with a previously published and validated NO consumption assay using an NO chemiluminescence analyzer (Sievers, Boulder CO). ${ }^{34}$ Additional experimental detail are summarized in the on-line supplement. 


\section{Arginase-1 assay}

Plasma levels of arginase-1 were measured via ELISA (Human Arginase 1 ELISA-Test-kit, Hycult biotechnology BV, Netherlands) according to the manufacturer's instructions and our previous publications. ${ }^{35}$

\section{EPR spin trap detection of ROS and free iron}

The spin probe CPH (Alexis, USA), was added to each stored red blood cell supernatant sample to achieve a final concentration of $200 \mu \mathrm{M}$. Samples were placed in $50 \mu \mathrm{L}$ glass capillaries and analyzed on a Bruker eScan Spectrometer at $37^{\circ} \mathrm{C}$ and $21 \% \mathrm{O}_{2}$. Spectra were signal averaged (5 scans over 10 minutes). The instrument settings were as follows: field sweep 50G; microwave frequency $9.78 \mathrm{GHz}$; microwave power $20 \mathrm{~mW}$; modulation amplitude 2G; conversion time $327 \mathrm{~ms}$; time constant $655 \mathrm{~ms}$; and receiver gain $1 \times 10^{5}$. To evaluate whether the signal was derived from non-transferrin bound iron versus reactive oxygen species a variety of reagents were added as indicated in the results, including allopurinol, $L$-nitroargine methyl ester ( $L$-NAME) and diphenyleneiodonium chloride (DPI), and catalase (Sigma, St. Louis, MO), CuZn superoxide dismutase (OXIS International Inc. Portland, OR), and deferoxamine mesylate (Sigma, St. Louis, MO).

\section{Detection and quantification of red blood cell microparticles}

Quantification of microparticles was performed at 14-day intervals for each unit of packed red blood cells. Two $\mu \mathrm{L}$ of PE-Cy 5 conjugated glycophorin A (BD Pharmingen, San Jose, CA) was added to $5 \mu \mathrm{L}$ packed red blood cells. After incubation for 30 minutes in the dark at room temperature, $2 \mu \mathrm{L}$ FITC conjugated Annexin V was added followed by $500 \mu \mathrm{L}$ Annexin V binding buffer, per kit instructions (Annexin V- FITC Kit, Beckman Coulter, Bera, CA). After 30 minutes of incubation in the dark at room temperature the analysis was performed using a CyAn ADP cytometer (Beckman Coulter, Miami FL). An effort was made to acquire a total of 100,000 events per sample at rates not exceeding 10,000 events/ second. The cytometer was calibrated to predetermined photomultiplier target channels prior to each use, using 8-peak Rainbow Calibration Particles (Spherotech, Libertyville, IL, Cat. No. RCP-30-5A). Offline spectral compensation and analyses were performed using the VenturiOne analysis package (Applied Cytometry, Dinnington, Sheffield, UK). Flow cytometric histograms of forward light scatter and fluorescence intensity are displayed on a 4-decade logarithmic scale. Microparticles were quantified as a percent of GPA positive events. The fraction of hemoglobin contained in microparticles compared with the total hemoglobin in the plasma of stored blood was measured by differential centrifugation at 750 $\times \mathrm{g}$ for 10 minutes at $4 \mathrm{C}$ for the first spin and $37,000 \times \mathrm{g}$ for 10 minutes for the second spin.

\section{Stopped flow analysis}

Hemoglobin was purified and NO-saturated buffers prepared as described previously. ${ }^{33}$ For these experiments a unit of outdated packed red blood cells with ACD anticoagulant was purchased from Interstate Blood Bank, Inc. (Memphis, TN). The microparticles were isolated as previously described. ${ }^{36}$ The absence of red blood cells in the microparticle preparation was confirmed by microscopy. The physical stability of microparticles over time was confirmed by measuring the free hemoglobin concentration in a microparticle preparation that had been left at $4{ }^{\circ} \mathrm{C}$ for 7 days. Free hemoglobin in a one day old preparation was not detectable by absorbance (intensity in the Soret range).

Stopped-flow experiments of the reaction between NO and free hemoglobin as well as with red cell-encapsulated hemoglobin and microparticle-encapsulated hemoglobin were performed as described previously ${ }^{37}$ and in described in detail in the supplementary methods section. Briefly, one syringe of the stopped-flow apparatus was loaded with NO 
saturated buffer, another with oxygenated cell free hemoglobin, red cell-encapsulated hemoglobin or microparticle-encapsulated hemoglobin, and a third syringe was loaded with deoxygenated PBS for dilution purposes. The hemoglobin concentration after mixing was $0.05 \mathrm{mM}$ in heme and the NO was 1-8 times in molar excess to heme. An upper bound for the dead time of the Stopped Flow instrument was estimated using a procedure similar to that described by Tonomura et. al. ${ }^{38}$ as $16.4 \pm 7.4$ mseconds by observing the reduction of 2,6-dichlorophenolindophenol (DCIP) by L-ascorbic acid.

Photolysis experiments to measure the very fast dioxygenation rate of NO by microparticles compared with cell free hemoglobin were performed under aerobic conditions similarly to those described previously 39 and in described in detail in the supplementary methods section for time-resolved absorption measurements. A solution of microparticleencapsulated hemoglobin or cell free hemoglobin was mixed 1:1 with a solution of the caged NO donor compound, potassium pentachloronitrosyl-ruthenate (II). A quantum yield of $\mathrm{NO}$ in each experiment was calculated from each observed reaction rate between cell free hemoglobin and $\mathrm{NO}$ and a $5 \times 10^{7} \mathrm{M}^{-1} \mathrm{~s}^{-1}$ bimolecular rate constant for NO scavenging by free oxyhemoglobin ${ }^{40}$, a lower bound which we have previously established. Each obtained value for the yield of NO was used to calculate a corresponding bimolecular rate constant for every observed reaction rate between microparticle-encapsulated hemoglobin and NO. The absence of lysis of microparticles during a photolysis experiment was confirmed by measuring the absorbance of the supernatant after photolysis, which showed no detectable amount of cell free hemoglobin. The age of blood used for preparation of vesicles for photolysis experiments was 28 or 33 days old.

\section{Rat vasoactivity model}

This study was reviewed and approved by the ethical committee for animal subjects of the University of Pittsburgh, PA, USA. Wistar male rats (Charles River, Wilmington, MA) with a body weight of $325 \pm 4 \mathrm{~g}$ (mean \pm SEM) were utilized in this study.

Rats were anesthetized with an intraperitoneal injection of a mixture of $90 \mathrm{mg} / \mathrm{kg}$ ketamine (Ketaject, Phoenix, St. Joseph, MD), $0.5 \mathrm{mg} / \mathrm{kg}$ medetomidine (DexDomitor; Pfizer,\#6295), and $0.005 \mathrm{mg} / \mathrm{kg}$ atropine sulfate (Med-Pharmex, Pomona, CA). Details of experimental setup are summarized in the on-line supplement. A fluid-filled catheter was inserted into the right carotid artery catheter and connected to a pressure transducer (model MLT844, AD instruments, Colorado Springs, CO) that was connected to a data acquisition system (Powerlab 8/30, AD Instruments) for continuous monitoring of mean arterial blood pressure (MAP) and heart rate. MAP was calculated with the use of the formula: (systolic blood pressure - diastolic blood pressure) $/ 3+$ diastolic blood pressure. In addition, the jugular vein was cannulated to infuse maintenance anesthesia (ketamine, $58 \mathrm{mg} / \mathrm{kg} / \mathrm{hr}$ in Ringer's solution). The femoral artery was cannulated for blood withdrawal and arterial blood-gas sampling. The femoral vein was cannulated for the infusion of the packed red blood cell supernatant.

After surgery, the rat was allowed to stabilize for 30 minutes after which $0.2 \mathrm{~mL}$ of blood was drawn for blood gas analysis. As replacement for the drawn blood $0.2 \mathrm{~mL}$ of $6 \%$ Hextend in Ringer's lactate (Hospira, Lake Forest, IL) was infused and the rat was allowed to stabilize for 10 minutes. Subsequently a volume of $4.95 \mathrm{~mL} / \mathrm{kg}$ of supernatant from either 4 or 39 days stored packed red blood cells was infused for approximately $40 \mathrm{~min}$ at a rate of $7.5 \mathrm{ml} / \mathrm{kg} / \mathrm{hr}$. Responses in blood pressure and heart rate were recorded continuously up to an hour after the end of the infusion. Experiments were performed on 5 individual days. Each day, the effect on blood pressure of infusion of packed red blood cell supernatant from the same red cell donor obtained at day 4 and day 39, from the same bag and frozen at -80 ${ }^{\circ} \mathrm{C}$, was determined in two separate rats. In the purified human hemoglobin experiments, 
$1.35 \mathrm{~mL} / \mathrm{kg}$ of a $13 \mathrm{~g} / \mathrm{dL}$ hemoglobin solution (or methemoglobin, cyanomethemoglobin) in PBS or $1.35 \mathrm{~mL} / \mathrm{kg}$ of a $6 \%$ Hetastarch was infused for approximately $10 \mathrm{~min}$ at a rate of 7.5 $\mathrm{ml} / \mathrm{kg} / \mathrm{hr}$. Additional experiments with infusion of microparticles are summarized in the supplemental on-line methods.

\section{Statistical methods}

Analysis was performed using Microsoft Office Excel 2007 (Redland, OR), Graphpad Prism, version 5 (Graphpad Software, LaJolla, CA), Systat Version 12 ( Systat Software Inc, Chicago, IL) and OriginPro 8 (OriginLab Corp.,Northampton, MA) software. Time course experiments of banked blood were analyzed by repeated measures analysis of variance (RMANOVA) with post-test Bonferroni corrections for multiple comparisons at each time point.

\section{Results}

\section{Accumulation of plasma ferrous oxyhemoglobin $\left(\mathrm{Fe}^{+2}-\mathrm{O}_{2}\right)$ during red blood cell storage}

It is known that progressive low level hemolysis occurs during standard red blood cell storage in ADSOL preservation solution, a result that we confirm in our 9 packed red blood cell units (Figure 1A and 1B). The cell free plasma hemoglobin concentration (measured in heme) in supernatants from 9 packed red blood cell units increased over time from a baseline 4 day mean of $11.6 \pm 2.5 \mu \mathrm{M}$ (range of 4.6 to $27.7 \mu \mathrm{M}$ ) to a 39 day mean value of $81.0 \pm 18.4 \mu \mathrm{M}$ (range of 31.0 to $173.3 \mu \mathrm{M}$ ). While our primary analysis was performed in non-leukoreduced blood, which is the standard at our center, we also performed the experiments in leukoreduced blood. There were no significant differences in the levels of plasma hemoglobin at 39 days of storage (non-leukoreduced $81.0 \pm 18.4 \mu \mathrm{M} \pm \mathrm{vs}$. leukoreduced $88.10 \pm 47.84 \mu \mathrm{M})$. Because low levels of plasma hemoglobin in the ferrous redox state (oxyhemoglobin or deoxyhemoglobin, but NOT methemoglobin) have the capacity to react with and inactivate NO via the classic dioxygenation reaction (Eq. 1) we quantified both the extent of hemolysis and the redox state of the cell free plasma hemoglobin in supernatant over 39 days in blood from nine normal blood donors.

$\mathrm{Fe}^{+2}-\mathrm{O}_{2}$ (oxyhemoglobin $)+\mathrm{NO}($ nitric oxide $) \rightarrow \mathrm{Fe}^{+3}$ (methemoglobin $)+\mathrm{NO}_{3}{ }^{-}$(nitrate)

While it might be expected that cell-free plasma hemoglobin would be oxidized to ferric methemoglobin over 39 days of storage, which could not catabolize NO, we have previously found that normal human plasma actively reduces ferric heme to ferrous heme. ${ }^{34}$ To explore the redox status of the cell free plasma hemoglobin during red cell storage we measured the concentration and percentages of methemoglobin, oxyhemoglobin and deoxyhemoglobin by UV-visible spectroscopy and least-squares spectral deconvolution. To some surprise, we found that at least $92 \%$ of the cell free plasma hemoglobin remained in the ferrous oxyhemoglobin $\left(\mathrm{Fe}^{+2}-\mathrm{O}_{2}\right)$ form (Figure 1C and 1D). The deconvolution model had a larger fitting error at 4 days of storage due to the lower overall hemoglobin levels, and hence lower absorbance signals.

\section{Cell free plasma hemoglobin and microparticles released during red blood cell storage stoichiometrically consumes NO via the dioxygenation reaction}

Ferrous oxyhemoglobin is known to react with $\mathrm{NO}$ via the dioxygenation reaction to form methemoglobin and nitrate (Eq. 1). ${ }^{41}$ Consistent with its redox status measured by spectral deconvolution we hypothesized that one heme would react with and consume one NO via this reaction. To measure $\mathrm{NO}$ catabolism we injected supernatant from packed red blood cell units taken at one week intervals from 4 to 39 days into an anaerobic solution of NO, generated from the NO donor DETANOate. ${ }^{34}$ As shown in Figure $1 \mathrm{E}$ we found that the 
concentration of NO consumed increased dramatically with red cell storage time. Suggesting a 1:1 reaction stoichiometry, the concentration of NO consumed rose to a similar extent as the concentration of cell free plasma hemoglobin (concentration measured and reported in terms of heme; Figure 1F). Indeed, the association between measured stored red cell supernatant heme vs. NO was highly significant as measured using a linear mixed-effects model (beta heme $=0.98, \mathrm{p}<0.001$; Figure $1 \mathrm{G}$ ), indicating a reaction of 1 mole of heme with one mole of NO, consistent with Eq. 1. This is interesting as it indicates that hemoglobin remains in the reduced form capable of NO scavenging even after 39 days of storage.

In addition to $\mathrm{NO}$ dioxygenation reactions that could modulate NO bioavailabilty, human red cells also contain arginase-1, which metabolizes arginine to ornithine and thus reduces arginine bioavailability for de novo NO synthesis. We found that the stored red cell supernatant contains increasing concentrations of erythrocyte arginase-1 ranging from an average of $280 \pm 69 \mathrm{ng} / \mathrm{mL}$ at 4 days of storage to $4633 \pm 631 \mathrm{ng} / \mathrm{mL}$ at 39 days of storage (Figure 1H). We also found that the amount of cell free plasma hemoglobin and arginase-1 correlated significantly for each individual unit of packed red blood cells with $\mathrm{R}^{2}$ values for nine units ranged from 0.81-0.99 (all $\mathrm{P}$ values $<0.015$; Table 1 ). While cell-free hemoglobin to arginase-1 correlation was high for individual units, when data from all units was combined the $\mathrm{R}^{2}$ value dropped to 0.51 indicating that the hemoglobin to arginase- 1 ratio varied considerably among donors.

\section{Red blood cell microparticles inactivate NO at rates approaching cell-free hemoglobin}

It has been known that stored red cells undergo membrane oxidation, damage and exocytosis to form microparticles. We measured these microparticles using flow cytometry of whole blood without centrifugation as shown in Figure 2A, for a representative unit of packed red blood cells at days 4, 18 and 32. A small proportion of microparticles are evident at 4 days, but they increase dramatically over time. The percent microparticles in the packed red blood cell units increased with storage duration (median values were $0.24 \%, 0.37 \%$, and $1.99 \%$ of total events at days 4, 18 and 32, respectively; Figure 2B). The microparticle doubling time was 9.0 days (95\% CI: 7.7-10.7 days; $\mathrm{P}<0.001$ ) as determined by linear regression analysis.

While increases in microparticles have been appreciated for decades, to our knowledge the ability of these microparticles to react with NO faster than red cells has never been evaluated. Because the dioxygenation reaction of $\mathrm{NO}$ with hemoglobin (Eq. 1) is limited by compartmentalization within a red blood cell, which is substantially determined by red cell size, we hypothesized that hemoglobin in small microparticles should react with NO much faster than hemoglobin contained in red blood cells. To measure the reaction rates we first performed time-resolved absorptions measurements using a stopped flow apparatus for red cells and microparticles reacting with NO. Time-resolved absorbance spectra of the reaction of $0.05 \mathrm{mM}$ red cell-encapsulated hemoglobin with $0.1 \mathrm{mM}$ NO using the stopped-flow apparatus is described by an observed rate constant of $2.8 \mathrm{~s}^{-1}$ (Figure 2C). Consistent with previous measurements 37,42 , this gives a bimolecular rate constant on the order of 1000 times slower than for the NO dioxygenation by oxygenated cell free hemoglobin and illustrates the dramatic slowing of NO dioxygenation by intact red blood cells. Figure 2D displays analogous absorbance data, but for a reaction between $0.05 \mathrm{mM}$ oxyhemoglobin encapsulated in microparticles and $0.05 \mathrm{mM}$ NO. This NO concentration provides the slowest possible reaction rate while allowing complete conversion of microparticleencapsulated hemoglobin into the ferric form. The only species visible in this case, methemoglobin, is the final product of the reaction. This is because the reaction is much faster than the reaction between red cell hemoglobin and $\mathrm{NO}$ and it is completely over within the dead time of the stopped flow apparatus. Assuming that it takes it least two lifetimes of the reaction until no kinetics may be observed, the lifetime of the dioxygenation of NO by microparticle-encapsulated hemoglobin must be less than or equal to half of the 
dead time of the stopped flow instrument. Considering the smallest NO concentration of $0.05 \mathrm{mM}$ used in the reaction, this gives a lower boundary on the dioxygenation bimolecular rate constant for microparticles of at least $2.4 \times 10^{6} \mathrm{M}^{-1} \mathrm{~s}^{-1}$. These studies indicated that the reaction of microparticles with $\mathrm{NO}$ is too fast to be observed by stopped-flow, similarly to the reaction of NO and cell-free hemoglobin.

To more accurately measure the kinetics of the reaction of $\mathrm{NO}$ with microparticles we employed a laser photolysis method and compared the results to those obtained using cellfree hemoglobin. A mixture of red cell microparticles or hemoglobin and a solution of the NO donor potassium pentachloronitrosyl-ruthenate(II) ("caged NO") was passed through a quartz flow cell and the caged NO was released by laser photolysis as described in the methods section. Figure 2E shows the time-resolved absorbance data collected from the reaction between $0.02 \mathrm{mM}$ cell-free oxyhemoglobin and a solution of $4 \mathrm{mM}$ caged NO. The NO yield for this reaction was calculated to be $155 \mu \mathrm{M}$ by using the observed rate of 7.75

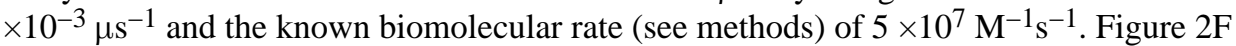
shows the absorbance spectra collected from a reaction of $0.02 \mathrm{mM}$ microparticleencapsulated hemoglobin and the same $4 \mathrm{mM}$ caged $\mathrm{NO}$ solution as that used in the experiment of Figure 2E. The observed rate constant for this data set was $2.74 \times 10^{-3}{\mu \mathrm{s}^{-1}}^{-1}$ giving a bimolecular rate constant of $1.77 \times 10^{7} \mathrm{M}^{-1} \mathrm{~s}^{-1}$ when calculated using the NO yield from Figure 2E. The average value for the bimolecular rate constant of the dioxygenation reaction between microparticles and $\mathrm{NO}$, for all experiments was $1.81 \pm 0.40 \times 10^{7} \mathrm{M}^{-1} \mathrm{~s}^{-1}$ $(\mathrm{n}=301,3$ separate experiments). Thus the dioxygenation reaction between microparticleencapsulated hemoglobin and NO is only 2.5 to 3 times slower than that for free hemoglobin reacting with $\mathrm{NO}$ and approximately 1000 times faster than the reaction with red cell encapsulated-hemoglobin, as measured by photolysis experiments and by stopped flow (Figure 2G). The inset of graph of panel (2G) shows the three biomolecular rate constants on a logarithmic scale, which more clearly highlights the similarity of the cell free hemoglobin and microparticle NO reaction rates and their large difference from red cellencapsulated hemoglobin. Hence, it is likely that in vivo microparticles will have an effect on NO bioavailability very similar to that of cell free plasma hemoglobin. This could be particularly important as microparticles are continuously elaborated after transfusion and are not known to be cleared by haptoglobin.

\section{Evaluation of reactive oxygen species and free iron formation during red blood cell storage}

We explored oxygen free radical generation in the stored red cell supernatant using EPR spin trapping. The hydroxylamine spin probe 1-hydroxy-3-carboxy-2,2,5,5tetramethylpyrrolidine $(\mathrm{CPH})$ reacts with reactive oxygen species (ROS) as well as free iron to form the $\mathrm{CP} \bullet$ radical which demonstrates a characteristic, 3 line EPR spectrum (Figure $3 \mathrm{~A})$. Incubation of the packed red blood cell supernatant with $\mathrm{CPH}$ for $10 \mathrm{~min}$ at $37^{\circ} \mathrm{C}$ produced a substantive $\mathrm{CP} \bullet$ radical that increased significantly after 18 days of storage (Figure 3B). The generation of the $\mathrm{CP} \bullet$ radical was inhibited in a dose dependant manner by the Fe chelator, deferoxamine suggesting free iron as the seminal reactant producing the $\mathrm{CP} \bullet$ signal $\left(\mathrm{Fe}^{3+}+\mathrm{CPH} \rightarrow \mathrm{Fe}^{2+}+\mathrm{CP} \bullet\right.$ ) rather than ROS (Figure 3C). To exclude contributions of ROS to the observed CP• formation and thus further support the interpretation that our signal was indeed dependent upon reaction of the spin probe and free iron, we exposed the packed red blood cell supernatants to the antioxidant enzymes catalase and superoxide dismutase, as well as a battery of inhibitors of enzymatic sources of ROS, (Figure 3D). Exposure of the 39-day samples to super oxide dismutase and/or catalase did not alter CP• radical production suggesting neither superoxide $\left(\mathrm{O}_{2}{ }^{\cdot-}\right)$ nor hydrogen peroxide derived hydroxyl radical were responsible for the observed signal. Furthermore, inhibition of NADPH oxidases, xanthine oxidase, aldehyde oxidase and nitric oxide synthases with the 
global FAD inhibitor, diphenyleneiodonium and/or specific inhibition of these enzymes (allopurinol for xanthine oxidase, raloxifene for aldehyde oxidase, $L$-NAME for both NO from nitric oxide synthase as well as $\mathrm{O}_{2}{ }^{--}$produced from uncoupled nitric oxide synthases) did not alter the $\mathrm{CP} \bullet$ intensity, confirming free iron as the seminal reactant responsible for our storage time-dependent $\mathrm{CP} \bullet$ radical formation from the packed red blood cell supernatants. These experiments suggest that effects of stored red cell supernatant on NO levels are not driven by ROS-mediated NO catabolism.

\section{Supernatant from stored red blood cells produces potent in vivo vasoconstriction in a rat model that correlates with the extent of in-storage hemolysis}

We have identified molecular mediators in stored red cell supernatant that have the potential to substantially impair NO signaling following red blood cell transfusion. In order to directly test whether these factors modulate vascular reactivity we infused the stored red cell supernatant from the stored red blood cell units into the rat systemic circulation and compared this with the supernatant from the same human blood donor that was obtained earlier at 4 days of storage. Infusions of stored red cell supernatant for each human donor unit were performed in two rats in the same day to control for potential time effects in the model. The mean cell free plasma hemoglobin concentration of the five packed red blood cell units used in this assay was $26 \pm 7 \mu \mathrm{M}$ (range 13-45 $\mu \mathrm{M}$ ) at 4 days of storage and $125 \pm$ $25 \mu \mathrm{M}$ (range $87-185 \mu \mathrm{M}$ ) at 39 days of storage. We infused $4.95 \mathrm{~mL} / \mathrm{kg}$ of stored red cell supernatant into the rats in order to model the amount infused with a 3-unit red blood cell transfusion into humans. We found that the 4-day old stored red cell supernatant increased MAP to a mean of $6 \pm 2 \%$ above baseline $(n=5)$ over the approximate 40 minute period of infusion. All five infusions of 39 day old stored red cell supernatant showed a greater increase in MAP compared to infusion of the corresponding supernatant that was obtained at 4 days of storage. The mean increase in normalized MAP after infusion of supernatant obtained at 39 days of storage was significantly higher $(\mathrm{p}=0.003)$ with an increase of $17 \pm 4$ $\%(n=5)$ in MAP above baseline (Figure 4A and 4B). There was a significant correlation $\left(\mathrm{R}^{2}=0.65\right)$ between the amount of hemoglobin present in the supernatant and the percentage increase in blood pressure above baseline (Figure 4C).

\section{Microparticle Hemoglobin content in stored blood plasma infused in rat experiments and half-life in vivo}

To quantify the concentration of hemoglobin contained in microparticles in aged blood infused in our experiments we measured hemoglobin concentrations in microparticles in the 9 units of banked human blood at 6-weeks of storage. In these samples we evaluated the concentration of microparticles after centrifugation speeds of $2700 \mathrm{~g}$, which was the protocol used to prepare the plasma. Note that quantification of microparticles by flow cytometry in Figure 2A and 2B was measured in uncentrifuged stored units. The levels of microparticles were determined by measuring the hemoglobin concentration by Drabkin's reagent before and after centrifugation at $37,000 \mathrm{~g}$ to remove all microparticles. The median percentage of hemoglobin in the plasma contained in microparticles was $10.4 \%$ (minimum $=3.2 \%$, maximum $=23.7 \%$. The mean \pm SEM was $11.6 \% \pm 2.2 \%$. The hemoglobin concentration of these microparticles had a median of $9.1 \mu \mathrm{M}$ (minimum $=1.1 \mu \mathrm{M}$, maximum $=17.2 \mu \mathrm{M})$ and a mean $\pm \mathrm{SE}$ of $8.5 \pm 2.2 \mu \mathrm{M}$. We also examined the amount of microparticles in 6 units of expired blood that was centrifuged at $750 \times \mathrm{g}$ and a median of $15 \%$ (minimum $=6 \%$, maximum $=40 \%$ ) of the plasma hemoglobin was contained in microparticles (mean \pm SEM measured $17.9 \% \pm 4.8 \%$. The hemoglobin concentration of these microparticles had a median of $30.2 \mu \mathrm{M}($ minimum $=3.4 \mu \mathrm{M}$, maximum $=56.6 \mu \mathrm{M})$ and a mean \pm SE of $31.9 \pm$ $9.3 \mu \mathrm{M}$. 
Estimation of microparticle clearance rates for human microparticles infused into our in vivo rat model was achieved by infusing human $\mathrm{RBC}$-derived microparticles into rats $(\mathrm{n}=2)$ and monitoring for human $\mathrm{Hb}$ in the rat plasma at selected time points (pre-infusion, 5, 10, 15, 20,30 and $45 \mathrm{~min}$ ). Microparticles were quantified by measuring the total human hemoglobin concentrations (ELISA) and by flow cytometry. We measured the double positive events (Glycophorin A-PE ${ }^{+}$Annexin V-FITC ${ }^{+}$) in the microparticle size range, enumerated based upon their ratio to a known amount of Absolute Count Standard fluorescent microbeads in each sample. As shown in Supplemental Figure 1 the half-life of human mircoparticles in our rat model is less than 15-20 minutes, consistent with our observed drop in MAP after cessation of infusion of stored blood plasma. In aggregate these experiments suggest that the majority of hemoglobin in our rat experiments is in the form of free plasma hemoglobin. However, the effect of microparticles may be more after transfusion of packed red blood cell units as these have higher quantites of microparticles and the transfused red cells will continue to elaborate microparticles after infusion.

\section{Concentrations of hemoglobin and redox status of hemoglobin necessary to induce vasoconstriction in the rat model}

Kinetic modeling suggests that levels of plasma hemoglobin as low as $1 \mu \mathrm{M}$ can limit NO bioavailability. ${ }^{43}$ These results notwithstanding, doubts have been expressed as to whether such low levels of plasma hemoglobin can significantly modulate in vivo vascular function. ${ }^{44}$ Consistent with these theoretical studies, prior experiments have shown reduced NO responsiveness in rabbit tissues infused with as little as $6 \mu \mathrm{M}$ hemoglobin (all concentrations in terms of heme), and we have found that vasodilator responsiveness to NO donor (nitroprusside) are blunted by $80 \%$ in patients with sickle cell anemia who had plasma heme concentrations greater than or equal to $6 \mu \mathrm{M} .{ }^{26}$ Despite these data, a number of investigators suggest that these low levels of plasma hemoglobin cannot modulate vascular function. ${ }^{44}$ In order to directly test whether the low concentrations of cell-free plasma hemoglobin present in packed red blood cells are capable of producing vasoconstriction we infused a human hemoglobin solution over 10 minutes and evaluated the changes in MAP vs. the cell free plasma hemoglobin concentration. As shown in Figure 5A (and inset), infusion of human oxyhemoglobin produces a robust and immediate vasoconstrictive effect, even at levels below $10 \mu \mathrm{M}$. To determine if this is related to the NO dioxygenation reaction (eq. 1) versus a colloid osmotic property or the generation of ROS by the ferric form of hemoglobin (methemoglobin or ferryl-hemoglobin) we compared the infusions of oxyhemoglobin to the same concentration of methemoglobin and cyanomethemoglobin. The latter species is "locked" in a redox inactive form which cannot bind oxygen or participate in redox reactions, and represents a more rigorous control for colloid osmotic property effects. As shown in Figure 5B, there were no significant differences between methemoglobin and cyanomethemoglobin, while ferrous oxyhemoglobin produced a robust vasoconstriction. Finally, in separate experiments we infused oxyhemoglobin and serially sampled the plasma from the rat for measurement of $\mathrm{NO}$ consumption during continuous infusion. As shown in Figure 5C, the infusion of oxyhemoglobin produced a dose dependent increase in the NO consumption within plasma, that was of similar magnitude to the levels of plasma hemoglobin in the circulation, consistent with a mechanism mediated by rapid NO dioxygenation (scavenging). As indicated in reference 44 this concept is still very controversial. Our results are the first to show that such low concentrations of heme (6 microM) scavenge $\mathrm{NO}$ and produce vasoconstriction, and the first to compare this response with an exact hemoglobin control, cyanomethemoglobin. 


\section{Discussion}

In these studies, we have examined the novel hypothesis that a component of the storage lesion is directly related to in vitro and in vivo hemolysis with dysregulation of redox pathways in NO signaling mediated by catabolism of NO and arginine. Previous studies have documented substantial hemolysis that increases cell free plasma hemoglobin as a function of time, reaching $28 \mu \mathrm{M}$ (in heme) in packed red blood cells on average after 35 days of storage in citrate-phosphate-dextrose-adenine anticoagulant (CPDA). ${ }^{20}$ Another study reported up to an average of $593 \mu \mathrm{M}$ (in heme) after storage for 35 days in CPDA. ${ }^{21}$ More recently, hemolysis was reported to be about $0.8 \%$ by day 50 of storage. ${ }^{22}$ This is approximately $80 \mu \mathrm{M}$ heme and consistent with our measurements in ADSOL. Given the low threshold for acceptable red blood cell viability (70\% post-transfusion) in current guidelines, we suggest that intravascular hemolysis and elaboration of microparticles after transfusion may also be considerable.

A central problem with hemolysis in stored blood may involve the effects on NO bioavailability. Nitric oxide plays several major roles in human physiology. Nitric oxide functions as a neurotransmitter, a macrophage-derived host-defense molecule, inhibits platelet aggregation and endothelium adhesion molecule expression, is an antioxidant, and is a potent vasodilator. ${ }^{45,46}$ To elicit its vasodilatory activity, $\mathrm{NO}$ must diffuse to the smooth muscle cells and activate sGC. In 1994, Lancaster suggested that the endothelium's proximity to millimolar concentrations of hemoglobin, would severely compromise the efficiency of the NO/sGC pathway. ${ }^{47}$ Hemoglobin scavenges NO primarily through a classic dioxygenation reaction, where NO reacts with oxyhemoglobin to form methemoglobin (where the heme irons are ferric) and nitrate (Eq. 1). This reaction, involving the oxidation of the ferrous heme iron $\left(\mathrm{Fe}^{+2}\right)$ to a ferric iron $\left(\mathrm{Fe}^{+3}\right)$, occurs at a rate of $6-8 \times 10^{7}$ $\mathrm{M}^{-1} \mathrm{~s}^{-1} \cdot{ }^{25,48,49}$ Because of the speed of this reaction, $\mathrm{NO}$ can only diffuse about $0.07 \mu \mathrm{m}$ (assuming a diffusion constant of $3000 \mu^{2} \mathrm{~s}^{-1}$ and 10 millimolar hemoglobin). Since NO is freely diffusible, the presence of hemoglobin on one side of the endothelium decreases the concentration of $\mathrm{NO}$ on the other side as well.

The reason that endothelial-derived NO does not undergo the dioxygenation reaction (Eq. 1) to the extent predicted, based purely on kinetic calculations, is that red blood cellencapsulated hemoglobin reacts with NO much more slowly than does cell free plasma hemoglobin. ${ }^{42,50-55}$ Three mechanisms contribute to reduced NO scavenging by red blood cells: (1) the rate of the reaction is largely limited by external diffusion of NO to the red blood cell; (2) NO diffusion is partially blocked by a physical barrier across the erythrocyte membrane; and (3) erythrocyte-encapsulated hemoglobin is efficiently compartmentalized in the lumen; it does not extravasate into the endothelium and interstitium. None of the three mechanisms responsible for reduced NO scavenging by hemoglobin encapsulated in intact red cells pertain to either free hemoglobin in plasma or to hemoglobin in microparticles, and all three of the mechanisms will break down upon hemolysis.

The enhanced ability of cell free plasma hemoglobin to scavenge NO has been widely attributed to the hypertension, increased systemic and pulmonary vascular resistance, and morbidity and mortality associated with administration of hemoglobin-based oxygen carriers (HbOCs or "blood substitutes"). ${ }^{56-60}$ Until recently, little attention has been paid to complications due to NO scavenging by cell free plasma hemoglobin in hemolytic disease, in part because the levels of plasma hemoglobin were so low. ${ }^{26,61}$ However, experiments show reduced NO responsiveness in rabbit tissues infused with as little as $6 \mu \mathrm{M}$ hemoglobin (all concentrations in terms of heme) ${ }^{62}$, and we found that vasodilator responsiveness to NO donor (nitroprusside) was blunted by $80 \%$ in patients with sickle cell anemia who had plasma heme concentrations greater than or equal to $6 \mu \mathrm{M} .{ }^{26} \mathrm{We}$ also demonstrated that 
intravascular hemolysis leads to vasoconstriction and impairs renal function in a canine intravascular hemolysis model. ${ }^{63}$ Indeed, accumulating transgenic animal, large animal and human epidemiological evidence supports a role for hemolysis in the pathobiology of sickle cell disease and other hemolytic anemias. ${ }^{29,30,63-67}$ In the current studies we confirm that levels of cell free plasma hemoglobin during acute infusions below $10 \mu \mathrm{M}$ increased MAP. We further found that this effect was in large part mediated by ferrous oxyhemoglobin, rather than methemoglobin or protein-dependent increases in colloid osmotic pressure.

Our current studies suggest that a 3-4 unit packed red blood cell transfusion of aged blood has the potential to inhibit systemic NO signaling. The effects of cell free plasma ferrous oxyhemoglobin would be compounded by the delivery of red cell microparticles, and the latter may be more important owing to the fact that they would be resistant to clearance by the haptoglobin-CD163 clearance system and through the kidneys. In this study we hypothesized and confirmed using advanced reaction measurements that red cell microparticles scavenge NO rapidly, with the potential to inhibit NO bioavailability in transfused blood.

We recognize that the ongoing steady-state levels of plasma hemoglobin in patients with hemolytic anemias, such as sickle cell disease, likely differ markedly from the situation after red blood cell transfusion, where plasma hemoglobin levels may only be transiently elevated following even substantial blood transfusions. Based on the relatively short half lives of both free hemoglobin and microparticles derived from transfused stored blood, the overall impact of transfusion on NO depletion and other effects of non-erythrocyte hemoglobin will be transient. Whether a transient inhibition in NO signaling is sufficient to increase the risk of multi-organ dysfunction or hemostatic activation in at-risk populations of patients remains to be determined.

Additional effects of hemolysis in stored blood were evaluated in our studies and may have contributed to the vasoactive effects we observed. One is the release of red cell arginase-1 into plasma. This enzyme converts arginine to ornithine, thus reducing arginine availability for NO synthesis. ${ }^{29,65}$ Arginasemia has been correlated with hemolysis in a number of human diseases and high enzyme activity is associated with the development of pulmonary hypertension and increased prospective mortality. Previous work has shown that arginase levels increase in stored blood as a function of time. ${ }^{68,69}$

\section{Conclusions}

Based on these studies showing that even low levels of cell free plasma hemoglobin are sufficient to inhibit endothelial NO signaling and induce vasoconstriction and hypertension, we propose that hemolysis and microparticle formation, as well as arginase- 1 release, during storage and after transfusion of aged erythrocytes contributes to decreased NO bioavailability and cardiovascular dysfunction. This effect may represent a contribution to organ injury in the susceptible host receiving multiple red blood cell transfusions. These studies suggest that new therapeutic avenues for red cell storage and transfusion should be studied. For example, methods to limit storage related hemolysis and microparticle formation using ATP sustaining preservation solutions, co-transfusion of hemoglobin scavenger molecules like haptoglobin or hemoglobin-binding peptides, red cell membrane stabilizing agents, as well as NO signaling/donor agents.

\section{Supplementary Material}

Refer to Web version on PubMed Central for supplementary material. 


\section{Acknowledgments}

We thank Zaharo Tsekouras for technical assistance.

Sources of Funding Mark Gladwin and Daniel Kim-Shapiro receive research support from NIH grant RO1HL098032. Dr. Gladwin also receives research support from the Institute for Transfusion Medicine and the Hemophilia Center of Western Pennsylvania.

\section{References}

1. The 2007 National Blood Collection and Utilization Survey Report. US Dept of Health and Human Services; Washington DC: 2009.

2. Vincent JL, Baron JF, Reinhart K, Gattinoni L, Thijs L, Webb A, Meier-Hellmann A, Nollet G, Peres-Bota D. Anemia and blood transfusion in critically ill patients. JAMA. 2002; 288:1499-507. [PubMed: 12243637]

3. Napolitano LM, Kurek S, Luchette FA, Corwin HL, Barie PS, Tisherman SA, Hebert PC, Anderson GL, Bard MR, Bromberg W, Chiu WC, Cipolle MD, Clancy KD, Diebel L, Hoff WS, Hughes KM, Munshi I, Nayduch D, Sandhu R, Yelon JA. Clinical practice guideline: red blood cell transfusion in adult trauma and critical care. Crit Care Med. 2009; 37:3124-57. [PubMed: 19773646]

4. Corwin HL, Gettinger A, Pearl RG, Fink MP, Levy MM, Abraham E, MacIntyre NR, Shabot MM, Duh MS, Shapiro MJ. The CRIT Study: Anemia and blood transfusion in the critically ill--current clinical practice in the United States. Crit Care Med. 2004; 32:39-52. [PubMed: 14707558]

5. Collins JA, James PM, Bredenberg CE, Anderson RW, Heisterkamp CA, Simmons RL. The relationship between transfusion and hypoxemia in combat casualties. Ann Surg. 1978; 188:513-20. [PubMed: 697435]

6. Fowler AA, Hamman RF, Good JT, Benson KN, Baird M, Eberle DJ, Petty TL, Hyers TM. Adult respiratory distress syndrome: risk with common predispositions. Ann Intern Med. 1983; 98:593-7. [PubMed: 6846973]

7. Martin AM Jr. Simmons RL, Heisterkamp CA 3rd. Respiratory insufficiency in combat casualties. I. Pathologic changes in the lungs of patients dying of wounds. Ann Surg. 1969; 170:30-8. [PubMed: 5819328]

8. Koch CG, Li L, Sessler DI, Figueroa P, Hoeltge GA, Mihaljevic T, Blackstone EH. Duration of redcell storage and complications after cardiac surgery. New Engl J Med. 2008; 358:1229-1239. [PubMed: 18354101]

9. de Watering LV, Lorinser J, Versteegh M, Westendord R, Brand A. Effects of storage time of red blood cell transfusions on the prognosis of coronary artery bypass graft patients. Transfusion. 2006; 46:1712-1718. [PubMed: 17002627]

10. Vandromme MJ, McGwin G Jr. Marques MB, Kerby JD, Rue LW 3rd, Weinberg JA. Transfusion and pneumonia in the trauma intensive care unit: an examination of the temporal relationship. J Trauma. 2009; 67:97-101. [PubMed: 19590316]

11. Weinberg JA, McGwin G Jr. Marques MB, Cherry SA 3rd, Reiff DA, Kerby JD, Rue LW 3rd. Transfusions in the less severely injured: does age of transfused blood affect outcomes? J Trauma. 2008; 65:794-8. [PubMed: 18849793]

12. Leal-Noval SR, Rincon-Ferrari MD, Garcia-Curiel A, Herruzo-Aviles A, Camacho-Larana P, Garnacho-Montero J, Amaya-Villar R. Transfusion of blood components and postoperative infection in patients undergoing cardiac surgery. Chest. 2001; 119:1461-8. [PubMed: 11348954]

13. Zallen G, Offner PJ, Moore EE, Blackwell J, Ciesla DJ, Gabriel J, Denny C, Silliman CC. Age of transfused blood is an independent risk factor for postinjury multiple organ failure. Am J Surg. 1999; 178:570-2. [PubMed: 10670874]

14. Edgren G, Kamper-Jorgensen M, Eloranta S, Rostgaard K, Custer B, Ullum H, Murphy EL, Busch MP, Reilly M, Melbye M, Hjalgrim H, Nyren O. Duration of red blood cell storage and survival of transfused patients (CME). Transfusion. 2010; 50:1185-95. [PubMed: 20158690]

15. Triulzi DJ, Yazer MH. Clinical studies of the effect of blood storage on patient outcomes. Transfus Apher Sci. 2010; 43:95-106. [PubMed: 20656558] 
16. Tinmouth A, Fergusson D, Yee IC, Hebert PC. Clinical consequences of red cell storage in the critically ill. Transfusion. 2006; 46:2014-2027. [PubMed: 17076859]

17. Tinmouth A, Chin-Yee I. The clinical consequences of the red cell storage lesion. Transfus Med Rev. 2001; 15:91-107. [PubMed: 11309731]

18. Dumaswala UJ, Dumaswala RU, Levin DS, Greenwalt TJ. Improved red blood cell preservation correlates with decreased loss of bands 3, 4.1, acetylcholinestrase, and lipids in microvesicles. Blood. 1996; 87:1612-1616. [PubMed: 8608255]

19. Greenwalt TJ, Bryan DJ, Dumaswala UJ. Erythrocyte-Membrane Vesiculation and Changes in Membrane-Composition During Storage in Citrate-Phosphate-Dextrose-Adenine-1. Vox Sanguinis. 1984; 47:261-270. [PubMed: 6485302]

20. Latham JT, Bove JR, Weirich FL. Chemical and Hematologic Changes in Stored Cpda-1 Blood. Transfusion. 1982; 22:158-159. [PubMed: 7071919]

21. Aubuchon JP, Estep TN, Davey RJ. The Effect of the Plasticizer Di-2-Ethylhexyl Phthalate on the Survival of Stored Rbcs. Blood. 1988; 71:448-452. [PubMed: 3337906]

22. Salzer U, Zhu R, Luten M, Isobe H, Pastushenko V, Perkmann T, Hinterdorfer P, Bosman G. Vesicles generated during storage of red cells are rich in the lipid raft marker stomatin. Transfusion. 2008; 48:451-462. [PubMed: 18067507]

23. Greenwalt TJ, McGuinness CG, Dumaswala UJ. Studies in Red-Blood-Cell Preservation .4. Plasma Vesicle Hemoglobin Exceeds Free Hemoglobin. Vox Sanguinis. 1991; 61:14-17. [PubMed: 1949704]

24. Lutz HU, Liu SC, Palek J. Release of Spectrin-Free Vesicles from Human Erythrocytes During Atp Depletion .1. Characterization of Spectrin-Free Vesicles. Journal of Cell Biology. 1977; 73:548-560. [PubMed: 873988]

25. Herold S, Exner M, Nauser T. Kinetic and mechanistic studies of the NO*-mediated oxidation of oxymyoglobin and oxyhemoglobin. Biochemistry. 2001; 40:3385-95. [PubMed: 11258960]

26. Reiter CD, Wang X, Tanus-Santos JE, Hogg N, Cannon RO 3rd, Schechter AN, Gladwin MT. Cell-free hemoglobin limits nitric oxide bioavailability in sickle-cell disease. Nat Med. 2002; 8:1383-9. [PubMed: 12426562]

27. Greenwalt TJ. The how and why of exocytic vesicles. Transfusion. 2006; 46:143-52. [PubMed: 16398744]

28. Willekens FL, Werre JM, Kruijt JK, Roerdinkholder-Stoelwinder B, Groenen-Dopp YA, van den Bos AG, Bosman GJ, van Berkel TJ. Liver Kupffer cells rapidly remove red blood cell-derived vesicles from the circulation by scavenger receptors. Blood. 2005; 105:2141-5. [PubMed: 15550489]

29. Rother RP, Bell L, Hillmen P, Gladwin MT. The clinical sequelae of intravascular hemolysis and extracellular plasma hemoglobin - A novel mechanism of human disease. Jama-Journal of the American Medical Association. 2005; 293:1653-1662.

30. Morris CR, Kato GJ, Poijakovic M, Wang XD, Blackwelder WC, Sachdev V, Hazen SL, Vichinsky EP, Morris SM, Gladwin MT. Dysregulated arginine metabolism, hemolysis-associated pulmonary hypertension, and mortality in sickle cell disease. Jama-Journal of the American Medical Association. 2005; 294:81-90.

31. MacArthur PH, Shiva S, Gladwin MT. Measurement of circulating nitrite and S-nitrosothiols by reductive chemiluminescence. J Chromatogr B Analyt Technol Biomed Life Sci. 2007; 851:93105.

32. Yang BK, Vivas EX, Reiter CD, Gladwin MT. Methodologies for the sensitive and specific measurement of S-nitrosothiols, iron-nitrosyls, and nitrite in biological samples. Free RadicRes. 2003; 37:1-10.

33. Huang Z, Louderback JG, Goyal M, Azizi F, King SB, Kim-Shapiro DB. Nitric oxide binding to oxygenated hemoglobin under physiological conditions. Biochim Biophys Acta. 2001; 1568:252260. [PubMed: 11786232]

34. Wang X, Tanus-Santos JE, Reiter CD, Dejam A, Shiva S, Smith RD, Hogg N, Gladwin MT. Biological activity of nitric oxide in the plasmatic compartment. Proc Natl Acad Sci U S A. 2004; 101:11477-82. [PubMed: 15258287] 
35. Janka JJ, Koita OA, Traore B, Traore JM, Mzayek F, Sachdev V, Wang X, Sanogo K, Sangare L, Mendelsohn L, Masur H, Kato GJ, Gladwin MT, Krogstad DJ. Increased pulmonary pressures and myocardial wall stress in children with severe malaria. J Infect Dis. 2010; 202:791-800. [PubMed: 20662718]

36. Xiong Z, Cavaretta J, Qu L, Stolz DB, Triulzi D, Lee JS. Red blood cell microparticles show altered inflammatory chemokine binding and release ligand upon interaction with platelets. Transfusion. 2010; 51:610-621. [PubMed: 20738825]

37. Azarov I, Huang KT, Basu S, Gladwin MT, Hogg N, Kim-Shapiro DB. Nitric oxide scavenging by red blood cells as a function of hematocrit and oxygenation. J Biol Chem. 2005; 280:3902438032. [PubMed: 16186121]

38. Tonomura B, Nakatani H, Ohnishi M, Yamaguchiito J, Hiromi K. Test Reactions for a StoppedFlow Apparatus - Reduction of 2,6-Dichlorophenolindophenol and Potassium Ferricyanide by LAscorbic-Acid. Anal Biochem. 1978; 84:370-383. [PubMed: 626384]

39. Azarov I, He XJ, Jeffers A, Basu S, Ucer B, Hantgan RR, Levy A, Kim-Shapiro DB. Rate of nitric oxide scavenging by hemoglobin bound to haptoglobin. Nitric Oxide-Biol Chem. 2008; 18:296302.

40. Huang KT, Huang Z, Kim-Shapiro DB. Nitric Oxide Red Blood Cell Membrane Permeability at high and low Oxygen Tension. Nitric Oxide. 2007; 16:209-216. [PubMed: 17223595]

41. Eich RF, Li TS, Lemon DD, Doherty DH, Curry SR, Aitken JF, Mathews AJ, Johnson KA, Smith RD, Phillips GN, Olson JS. Mechanism of NO-induced oxidation of myoglobin and hemoglobin. Biochemistry. 1996; 35:6976-6983. [PubMed: 8679521]

42. Carlsen E, Comroe JH. The rate of uptake of Carbon Monoxide and of Nitric Oxide by normal and human erythrocytes and experimentally produced spherocytes. Journal of General Physiology. 1958; 42:83-107. [PubMed: 13575776]

43. Jeffers A, Gladwin MT, Kim-Shapiro DB. Computation of plasma hemoglobin nitric oxide scavenging in hemolytic anemias. Free Radical Biology and Medicine. 2006; 41:1557-1565. [PubMed: 17045924]

44. Bunn HF, Nathan DG, Dover GJ, Hebbel RP, Platt OS, Rosse WF, Ware RE. Pulmonary hypertension and nitric oxide depletion in sickle cell disease. Blood. 2010; 116:687-92. [PubMed: 20395414]

45. Schmidt PM, Schramm M, Schroder H, Wunder F, Stasch JP. Identification of residues crucially involved in the binding of the heme moiety of soluble guanylate cyclase. J Biol Chem. 2004; 279:3025-3032. [PubMed: 14570894]

46. Patel RP, McAndrew J, Sellak H, White CR, Jo HJ, Freeman BA, Darley-Usmar VM. Biological aspects of reactive nitrogen species. Biochim Biophys Acta-Bioenerg. 1999; 1411:385-400.

47. Lancaster JR. Simulation of the Diffusion and Reaction of Endogenously Produced Nitric-Oxide. Proc Natl Acad Sci U S A. 1994; 91:8137-8141. [PubMed: 8058769]

48. Doyle MP, Hoekstra JW. Oxidation of nitrogen oxides by bound dioxygen in hemoproteins. $\mathbf{J}$ Inorg Biochem. 1981; 14:351-8. [PubMed: 7276933]

49. Eich RF, Li T, Lemon DD, Doherty DH, Curry SR, Aitken JF, Mathews AJ, Johnson KA, Smith RD, Phillips GN Jr. Olson JS. Mechanism of NO-induced oxidation of myoglobin and hemoglobin. Biochemistry. 1996; 35:6976-83. [PubMed: 8679521]

50. Coin JT, Olson JS. Rate of Oxygen-Uptake by Human Red Blood-Cells. J Biol Chem. 1979; 254:1178-1190. [PubMed: 762123]

51. Butler AR, Megson IL, Wright PG. Diffusion of nitric oxide and scavenging by blood in the vasculature. Biochim Biophys Acta-Gen Subj. 1998; 1425:168-176.

52. Vaughn MW, Kuo L, Liao JC. Estimation of nitric oxide production and reaction rates in tissue by use of a mathematical model. Am J Physiol-Heart Circul Physiol. 1998; 274:H2163-H2176.

53. Vaughn MW, Huang KT, Kuo L, Liao JC. Erythrocyte consumption of nitric oxide: Competition experiment and model analysis (vol 5, pg 18, 2001). Nitric Oxide-Biol Chem. 2001; 5:425-425.

54. Liu XP, Miller MJS, Joshi MS, Sadowska-Krowicka H, Clark DA, Lancaster JR. Diffusion-limited reaction of free nitric oxide with erythrocytes. J Biol Chem. 1998; 273:18709-18713. [PubMed: 9668042] 
55. Azarov I, Huang KT, Basu S, Gladwin MT, Hogg N, Kim-Shapiro DB. Nitric oxide scavenging by red blood cells as a function of hematocrit and oxygenation. J Biol Chem. 2005:M509045200.

56. Vogel WM, Dennis RC, Cassidy G, Apstein CS, Valeri CR. Coronary Constrictor Effect of Stroma-Free Hemoglobin-Solutions. Am J Physiol. 1986; 251:H413-H420. [PubMed: 3740293]

57. Hess JR, Macdonald VW, Brinkley WW. Systemic and Pulmonary-Hypertension after Resuscitation with Cell-Free Hemoglobin. J Appl Physiol. 1993; 74:1769-1778. [PubMed: 8514695]

58. Lee R, Neya K, Svizzero TA, Vlahakes GJ. Limitations of the Efficacy of Hemoglobin-Based Oxygen-Carrying Solutions. J Appl Physiol. 1995; 79:236-242. [PubMed: 7559226]

59. Murray JA, Ledlow A, Launspach J, Evans D, Loveday M, Conklin JL. The Effects of Recombinant Human Hemoglobin on Esophageal Motor Function in Humans. Gastroenterology. 1995; 109:1241-1248. [PubMed: 7557091]

60. Ulatowski JA, Nishikawa T, MathesonUrbaitis B, Bucci E, Traystman RJ, Koehler RC. Regional blood flow alterations after bovine fumaryl beta beta-crosslinked hemoglobin transfusion and nitric oxide synthase inhibition. Critical Care Medicine. 1996; 24:558-565. [PubMed: 8612404]

61. Reiter CD, Gladwin MT. An emerging role for nitric oxide in sickle cell disease vascular homeostasis and therapy. Curr Opin Hematol. 2003; 10:99-107. [PubMed: 12579034]

62. Pohl U, Lamontagne D. Impaired Tissue Perfusion after Inhibition of Endothelium-Derived NitricOxide. Basic Research in Cardiology. 1991; 86:97-105. [PubMed: 1953621]

63. Minneci PCDK, Zhi H, Yuen PS, Star RA, Banks SM, Schechter AN, Natanson C, Gladwin MT, Solomon SB. Hemolysis-associated endothelial dysfunction mediated by accelerated NO inactivation by decompartmentalized oxyhemoglobin. J Clin Invest. 2005; 115:3409-17. [PubMed: 16294219]

64. Gladwin MT. Unraveling the hemolytic subphenotype of sickle cell disease. Blood. 2005; 106:2925-2926.

65. Kato GJ, McGowan VR, Machado RF, Little JA, Taylor VIJ, Morris CR, Nichols JS, Wang X, Poljakovic M, Morris J, Sidney M, Gladwin MT. Lactate dehydrogenase as a biomarker of hemolysis-associated nitric oxide resistance, priapism, leg ulceration, pulmonary hypertension and death in patients with sickle cell disease. Blood. 2006; 107:2279-2285. [PubMed: 16291595]

66. Nolan VG, Wyszynski DF, Farrer LA, Steinberg MH. Hemolysis-associated priapism in sickle cell disease. Blood. 2005; 106:3264-3267. [PubMed: 15985542]

67. Gladwin MT, Sachdev V, Jison ML, Shizukuda Y, Plehn JF, Minter K, Brown B, Coles WA, Nichols JS, Ernst I, Hunter LA, Blackwelder WC, Schechter AN, Rodgers GP, Castro O, Ognibene FP. Pulmonary hypertension as a risk factor for death in patients with sickle cell disease. New England Journal of Medicine. 2004; 350:886-895. [PubMed: 14985486]

68. Bernard A, Meier C, Lopez N, May J, Chang P, Boulanger B, Kearney P. Packed red blood cellassociated arginine depletion is mediated by arginase. Journal of Trauma-Injury Infection and Critical Care. 2007; 63:1108-1112.

69. Prins HA, Houdijk APJ, Nijveldt RJ, Teerlink T, Huygens P, Thijs LG, van Leeuwen PAM. Arginase release from red blood cells: Possible link in transfusion induced immune suppression? Shock. 2001; 16:113-115. [PubMed: 11508862] 


\section{Short Clinical Summary}

Transfusion of blood represents one of the most common medical therapies with over 14.5 million packed red blood cell units, or 48.9 units per thousand persons, administered in the United States per year. ${ }^{1}$ It is remarkable that approximately $40 \%$ of all critically ill patients receive at least one unit of packed red blood cells in the intensive care unit, with a mean of 5 units per patient. ${ }^{2-4}$ In recent years a growing body of literature has demonstrated an increased incidence of adverse clinical outcomes associated with the transfusion of a large number of units or, potentially, with increased storage time of the units. We now find that storage of human red blood cells under standard blood banking conditions results in progressive red blood cell hemolysis, with the accumulation of cell free and microparticle-encapsulated hemoglobin. This cell-free hemoglobin and red cell microparticles released during blood storage react with and destroy an important blood vessel dilating molecule called nitric oxide about 1000 times faster than intact red cells. This scavenging of nitric oxide increases with the age of blood in storage and produces vasoconstriction in animal models in proportion to the levels of cell-free hemoglobin and red cell microparticles that accumulate. These studies suggest that red blood cell hemolysis during storage and after transfusion could contribute to the observed adverse cardiovascular effects of transfusion. 

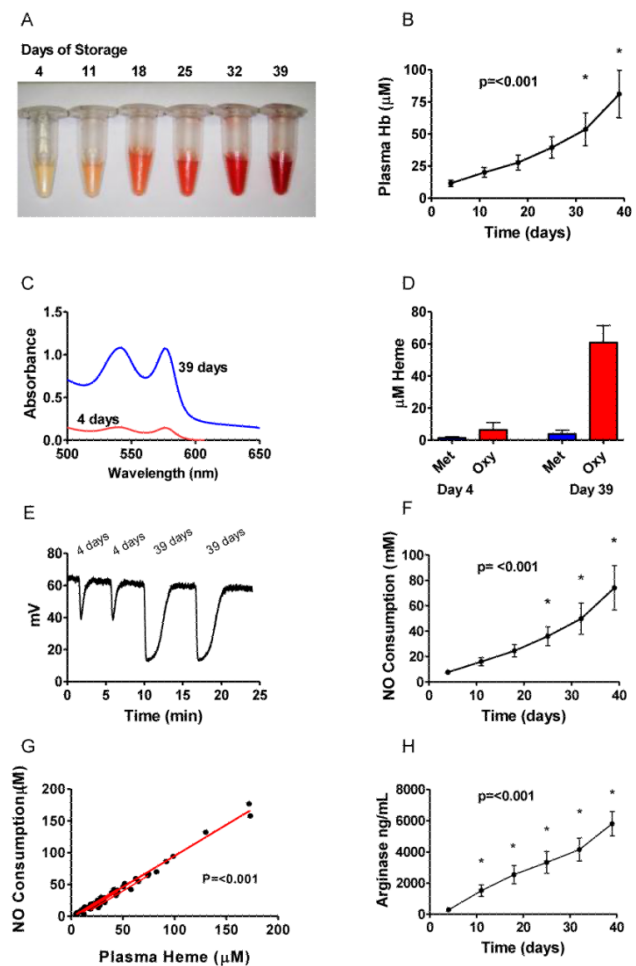

Figure 1. Cell Free hemoglobin and NO scavenging in stored blood

(A) Photograph of stored red blood cell supernatant over time. (B) Average cell free plasma heme concentration $(\mu \mathrm{M})$ over time. $(\mathbf{C})$ Absorbance spectra of representative packed red blood cell supernatants at 4 and 39 days of storage. (D) Concentration $(\mu \mathrm{M})$ of methemoglobin and oxyhemoglobin by spectral deconvolution of packed red blood cell supernatant. (E) Raw data for NO consumption assay. (F) NO Consumption over Time. (G) Nitric oxide consumption is directly proportional to the plasma heme concentration. (H) Arginase-1 levels increasing over time. Overall $P$ values show are for the significance of the change over time analyzed by RM-ANOVA. For panels $(\mathbf{B})$ and $(\mathbf{F})$ and $(\mathbf{H})$ an * represents a statistically significant difference of time points compared 4 days of storage by Bonferroni correction after RM-ANOVA. 

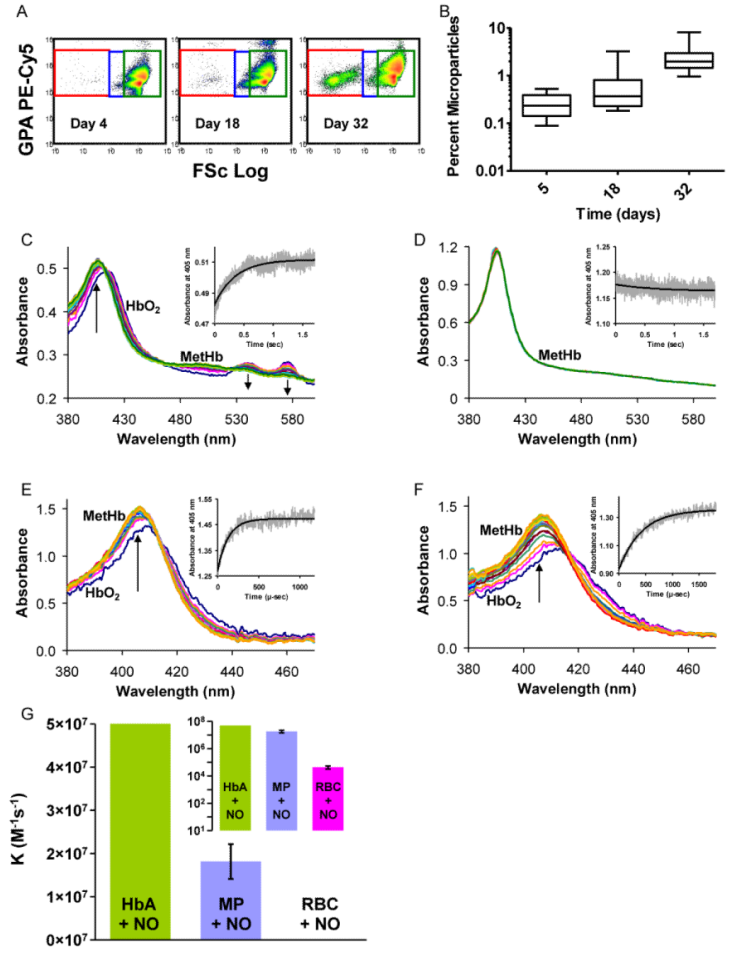

Figure 2. Microparticle formation and NO scavenging in stored blood

(A) The flow cytometry histograms show forward light scatter (FSc Log) versus fluorescence intensity of labeled glycophorin A PE-Cy5. Intact red blood cells have relatively high forward light scatter (green box). As they transition (blue box) to microparticles (MP) (red box) forward light scatter and GPA fluorescence intensity decrease. A small proportion of MPs are evident after short storage (4 days), but they increase significantly over time $(\mathbf{B})$. Microparticle median values were $0.24,0.37$, and $1.99 \%$ at days 4, 18 and 32 of storage, respectively. (C) A reaction between $0.05 \mathrm{mM}$ red cell-encapsulated oxyhemoglobin and $0.1 \mathrm{mM}$ NO measured by stopped-flow. The arrows point in the direction of changing absorbance at the methemoglobin peak of $405 \mathrm{~nm}$ and at the oxyhemoglobin peaks of 541 and $577 \mathrm{~nm}$. The inset shows absorbance at $405 \mathrm{~nm}$. (D) A reaction between $0.05 \mathrm{mM}$ microparticle-encapsulated oxyhemoglobin and $0.05 \mathrm{mM} \mathrm{NO}$ as measured by stopped-flow is too fast to be observed. (E) A reaction of $0.02 \mathrm{mM}$ cell-free oxyhemoglobin with NO in a photolysis experiment. The inset shows absorbance at $405 \mathrm{~nm}$. (F) A reaction of $0.02 \mathrm{mM}$ microparticle-encapsulated oxyhemoglobin with $\mathrm{NO}$ in a photolysis experiment. The caged NO solution used is the same as that in the experiment of panel E. (G) The measured bimolecular rate constants for the dioxygention of NO by microparticle- and red blood cell-encapsulated oxyhemoglobin compared with the rate for cell-free oxyhemoglobin. The inset displays these data on a logarithmic scale. 

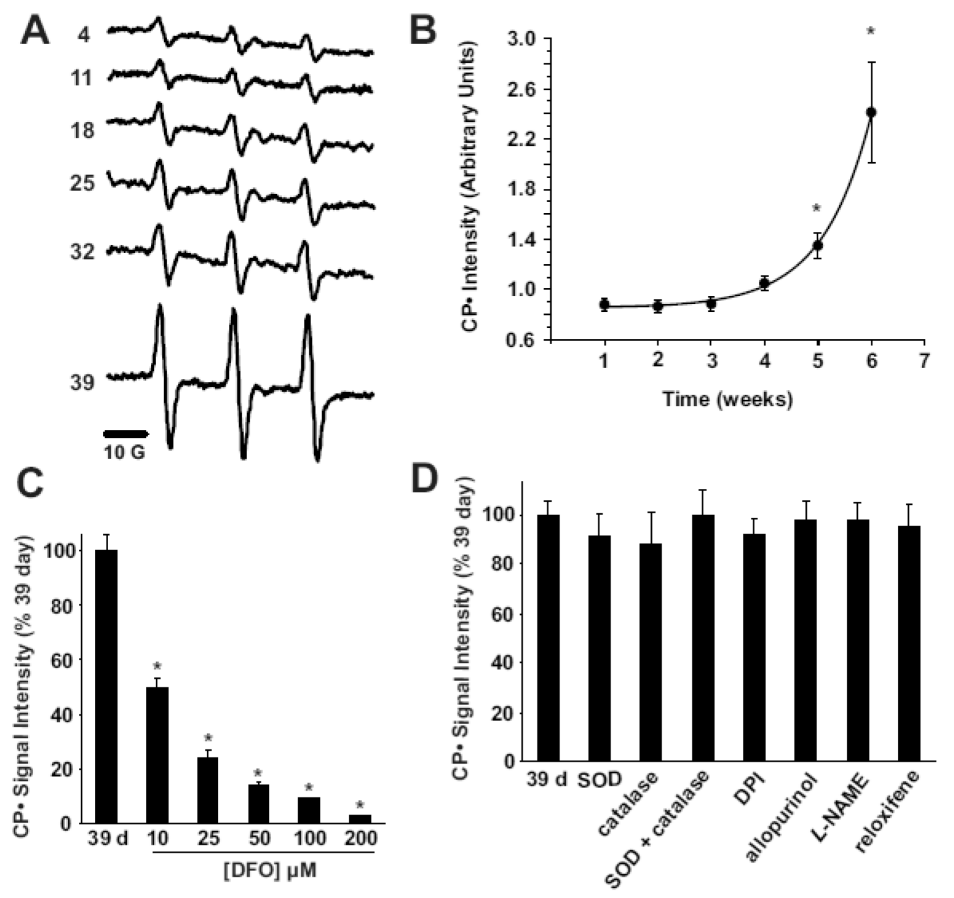

Figure 3. Storage of packed red blood cells induces time-dependent, iron-mediated radical formation

(A) Representative EPR spectra of CPH exposed to packed red blood cell supernatants for $10 \mathrm{~min}$ at $37^{\circ} \mathrm{C}$. Spectra represent a signal average of $5 \mathrm{scans}$ from $\mathrm{t}=9$ to $\mathrm{t}=10 \mathrm{~min}$. (B) The mean $\mathrm{CP} \bullet$ signal intensity is displayed versus time (weeks) of storage $(n=3)$, * indicates statistically significant from week 1 by Bonferroni correction of RM-ANOVA, P<0.05. (C) Supernatants from 39 day old packed red blood cells were exposed to $50 \mu \mathrm{M} \mathrm{CPH}$ in the presence of increasing concentrations $(10-200 \mu \mathrm{M})$ of deferoxamine, * indicates statistically significant from day 39 by Bonferroni correction of RM-ANOVA, P < 0.05. (D) Supernatants from 39 day old packed red blood cells were exposed to $50 \mu \mathrm{M} \mathrm{CPH}$ in the presence of SOD $(100 \mathrm{U} / \mathrm{mL})$, catalase $(100 \mathrm{U} / \mathrm{mL})$, SOD + catalase, diphenyleneiodonium (DPI) $(100 \mu \mathrm{M})$, allopurinol $(100 \mu \mathrm{M}), L$-NAME $(100 \mu \mathrm{M})$ and reloxifene $(100 \mu \mathrm{M})$. Data represent mean \pm SEM of at least three independent determinations and were not statistically significant. 


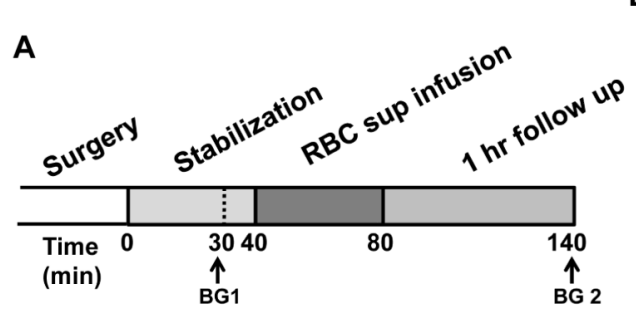

B

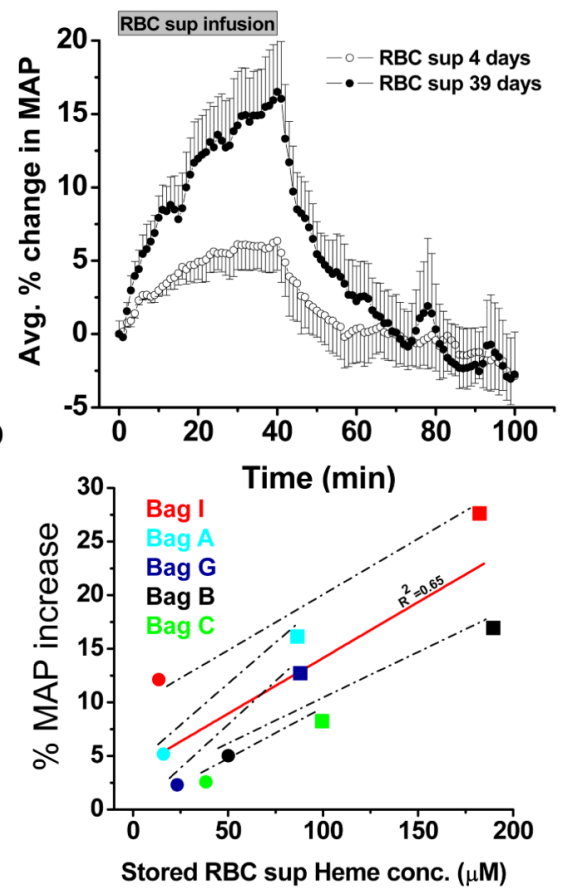

Figure 4. Vasoactivity of infused packed red cell supernatant/plasma

(A) Experimental time line for packed red cell supernatant infusions. Rats were stabilized for 30 minutes after surgery and blood gasses were drawn as indicated (BG 1 and 2).

Supernatant $(1.6 \mathrm{~mL})$ of packed red blood cells stored either for 4 or 39 days was infused for $40 \mathrm{~min}$, after which the rats were followed up for 1 hour $(\mathrm{n}=5)$. (B) Change in MAP over time after packed red blood cell supernatant infusion and 60 minute follow up. (C) Average percentage peak increase in MAP after infusion of packed red blood cell supernatants $(\mathrm{P}<$ 0.003). (D) Correlation (solid line) between the PRBC supernatant heme concentration and the percentage increase in MAP after a 40 minute infusion of either 4 days (O) or 39 days $(\square)$ stored PRBC supernatant $\left(\mathrm{r}^{2}=0.65\right)$. Each data point was obtained from a separate rat infusion experiment, in a different rat ( 2 groups of $n=5)$. All values are displayed as mean \pm SEM. A Student's t test was used to compare the two groups of rats. 

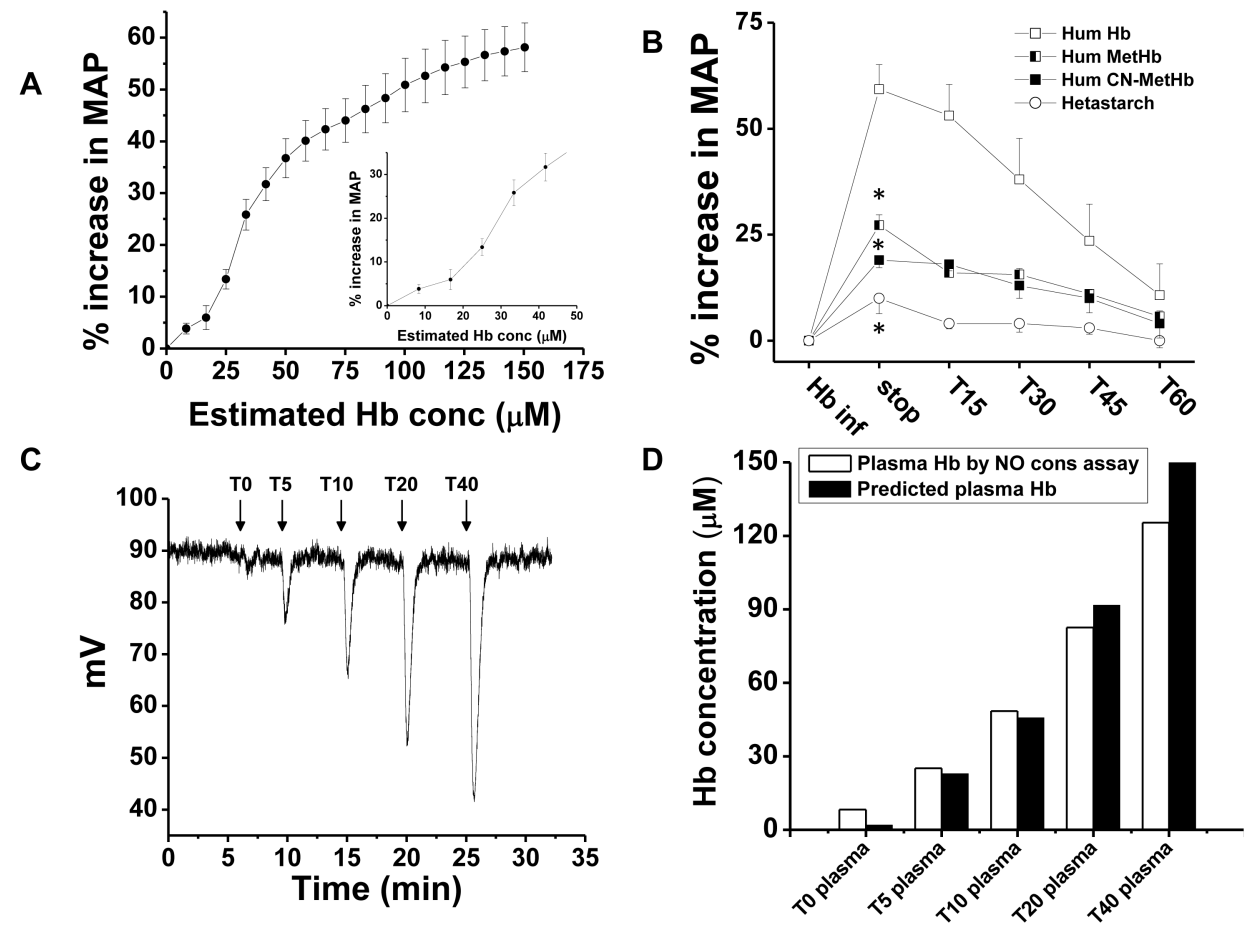

Figure 5. Low concentrations of ferrous oxyhemoglobin increase MAP in rats

(A) Percentage increase in MAP after infusion of human hemoglobin $(175 \mathrm{mg} / \mathrm{kg})$ as a function of estimated rat plasma hemoglobin concentration (expressed as heme) as calculated from the dilution of infused hemoglobin in rat plasma volume over the 10-min infusion time. The inset shows a magnification of the data for a plasma hemoglobin concentration between 0 to $60 \mu \mathrm{M}$. (B) Percentage increase in MAP after infusion of unmodified human hemoglobin $(\square)$ and after modification of human hemoglobin to methemoglobin $(\mathbf{D})$ or cyanomethemoglobin ( $\mathbf{\square})$ compared to infusion of the plasma expander hetastarch $($ 였 $)$. An * indicates a result that is significantly different $(\mathrm{P}<0.05)$ from hemoglobin by ANOVA. Methemoglobin vs cyanomethemoglobin was not statistically significant from each other by ANOVA. (C) Rat plasma samples obtained before (T0), and after 5, 10, 20 and $40 \mathrm{~min}$ (T5-40) of infusion of human hemoglobin and then were analysed by tri-iodide chemiluminescence for NO consumption. (D) The area under the peaks (NO consumption) was quantified (open bars) and compared with the levels of cell free plasma hemoglobin. 


\section{Table 1}

$\mathrm{R}^{2}$ and $\mathrm{p}$ values for arginase- 1 vs. cell free plasma hemoglobin for each unit of packed red blood cells. There are 6 sets of observations for each PRBC Unit.

\begin{tabular}{|lll|}
\hline PRBC Unit & $\mathbf{R}^{\mathbf{2}}$ & $\mathbf{p}$ value \\
\cline { 2 - 3 } A & 0.93 & 0.002 \\
$\mathbf{B}$ & 0.97 & $<0.001$ \\
$\mathbf{C}$ & 0.87 & 0.006 \\
$\mathbf{D}$ & 0.99 & $<0.001$ \\
$\mathbf{E}$ & 0.91 & 0.003 \\
$\mathbf{F}$ & 0.93 & 0.002 \\
$\mathbf{G}$ & 0.97 & $<0.001$ \\
$\mathbf{H}$ & 0.91 & 0.003 \\
$\mathbf{I}$ & 0.81 & 0.015 \\
\hline
\end{tabular}

